\title{
Recent Advancement in Studies of Deccan Trap and Its Basement; Carbonatites and Kimberlites - An Indian Perspective in Last Five Years
}

\author{
JYOTIRANJAN S RAY ${ }^{1}$ and G PARTHASARATHY ${ }^{2, *}$ \\ ${ }^{1}$ Physical Research Laboratory, Ahmedabad 380 009, India \\ ${ }^{2}$ School of Natural Sciences and Engineering, National Institute of Advanced Studies, Indian Institute of \\ Science Campus, Bengaluru 560 012, Karnataka, India
}

(Received on 06 May 2018; Accepted on 06 June 2018)

\begin{abstract}
We made an attempt to provide a status report on volcanic rocks and mantle derived rocks with a special focus on studies related to Deccan flood basalt, carbonatites and kimberlites from India, during last five years. The important problems related to the Deccan volcanism include 1. Origin of Deccan Trap whether plume related or impact induced or triggered volcanism (2) the details of composition, the internal structure and age distribution and (3) the relation between the large igneous provinces and major mass extinction. Carbonatites are mantle derived rocks, which are helpful in modelling the Earth's interior. They vary in age from Archean to recent, and are found mostly on continents and thus provide valuable information about the evolution of the sub-continental mantle through time. This article also reviews most of the research contributions on Indian carbonatites of the last five years. Building on existing information on their modes of occurrences, field dispositions, chronology, petrology and geochemistry, we use the recent data to provide a comprehensive view on the origin and evolution of these carbonatites.
\end{abstract}

Keywords: Deccan Trap; Kimberlites; Mantle Rocks; Carbonatites; Mineral Physics; Phyllosilicates

\section{Introduction}

Geological Society of India (GSI) has brought out many interesting review books and memoirs related to the Deccan Volcanic Province (Suubarao, 1999), kimberlites and related mantle derived rocks (Fareeduddin and Mitchell, 2012). In recent years there has been a tremendous growth in the field and laboratory data related to Deccan Trap and mantle derived rocks from India. The aim of the present work is to review some important findings related to the Deccan Trap, carbonatites and kimberlites from India with a special focus on the work carried out during the last half a decade.

The ca.65Ma Deccan volcanic terrain, forming one of the prominent large Igneous Provinces (LIP) on the surface of the earth, has remained seismically active since historical times, including the famous Reservoir Triggered Seismicity in the Koyna region (1967 Koyna Earthquake) the 1993 Killari earthquake
(Mw 6.3). Recently Gupta (2017) has edited a comprehensive collection of 25 original articles covering different geophysical aspects of Koyna Earthquake (Gupta 2017 and the references therein). In this article we provide a brief review of the work carried out in Deccan Volcanic Province near Killari region, which is equally important for the stable continental earth quake and geodynamic understanding. To study the seismotectonics of this earthquake-prone province in general and Killari earthquake region in particular, several boreholes were drilled in and around epicentral area. It included $617 \mathrm{~m}$ deep KLR-1 borehole, drilled $80 \mathrm{~m}$ south of surface scarp on the hanging wall near the Killari village ( $\left(18^{\circ} 03^{\prime} 07^{\prime \prime} \mathrm{N}, 76^{\circ} 33^{\prime} 20^{\prime \prime} \mathrm{E}\right)$. It penetrated 338 $\mathrm{m}$ thick basalt flows, followed by $8 \mathrm{~m}$ of infratrappean sediments and a further $270 \mathrm{~m}$ of the Neoarchean crystalline basement.

Detailed geoscientific studies (including seismic, elastic and petrophysical studies) on the representative

*Author for Correspondence: E-mail:drg.parthasarathy@gmail.com 
43 basement cores from various depths from the borehole indicated the Neoarchean crystalline basement to be made up of mainly amphibolite to granulite facies transitional, pervasively metasomatised, mid-crustal rocks with a few samples belonging to tonalite and granodiorite (Pandey et al., 2014, 2016a; Pandey 2016; Tripathi et al. 2012a, b; Tripathi 2015). The basalts are iron-rich compared to other basalts (average $\mathrm{FeO}_{\mathrm{T}}: \sim 9 \mathrm{wt} \%$ ) and characterised by an average density of $2.82 \mathrm{~g} / \mathrm{cm}^{3}$, with corresponding P- and S-wave velocities of 6.17 and $3.61 \mathrm{~km} / \mathrm{s}$ respectively. Retrogressive alterations like saussuritization, biotitization, sericitization and iron enrichment have severely affected these rocks, including the reduction in measured velocities by as much as 15\% (Pandey et al., 2016). Petrologically, they contain clinopyroxene, horneblend, calcic plagioclase biotite and minor orthopyroxene (Fig. 1), apart from accessories like ilmenite, magnetite, titanite, epidote etc. Geothermobarometric studies indicate that the basement below Killari was subjected to temperatures between 700 and $860^{\circ} \mathrm{C}$ and pressure, $5-7 \mathrm{~kb}$, ( Tripathi et al., 2012) before their exhumation to the surface indicating that almost $15-20 \mathrm{~km}$ granitic upper crust has been eroded from this region even before the onset of Deccan volcanism, due to persistent geodynamic process of uplift and erosion. Besides, this amphibolite granulite facies basement has halogen-rich amphiboles and mantle derived carbonates with $2 \mathrm{wt} \%$ of $\mathrm{CO}_{2}$ emanated from the mantle (Pandey et al., 2014). Carbon and oxygen

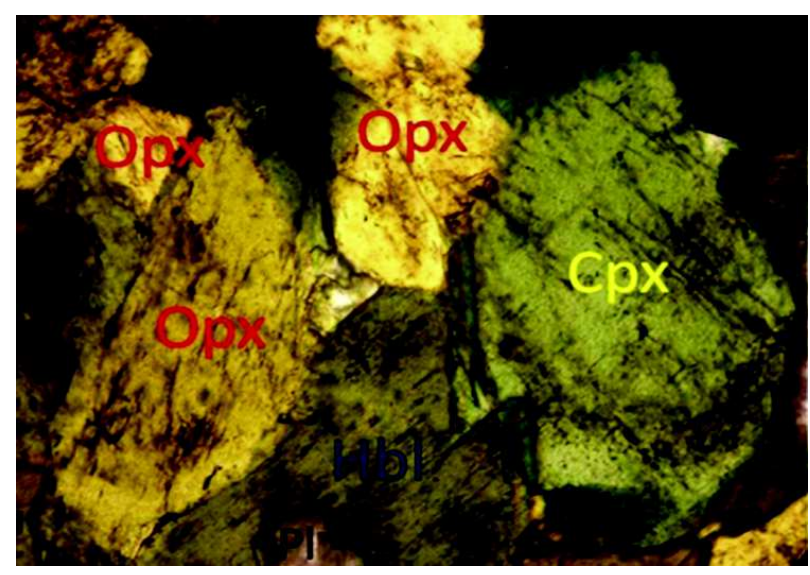

Fig. 1: Photomicrographs taken from thin section of the basement sample, KIL-12 from the KLR-1 borehole drilled in Killari. Hbl, Cpx, Opx and Plg refer to hornblende, clinopyroxene, orthopyroxene and plagioclase respectively isotopic studies on couple of extracted carbonate samples do confirm their mantle origin, suggesting large scale crust-mantle thermal fluid interaction beneath Killari seismic zone. Underlying mantle is still quite warm below areas covered by Deccan volcanics (Pandey et al., 2017). Rohilla et al. (2018) have made detailed analyses of shear wave velocity structure beneath Koyna region and found an unusually high upper crustal shear-wave velocity of about $4 \mathrm{~km} / \mathrm{s}$ at $5 \mathrm{~km}$ depth that is comparable with that of the lower crust.

However, not much study has been carried out on the $338 \mathrm{~m}$ thick volcanic sequence which is comprised of eight flows, belonging to two prominent formations, Ambenali and Poladpur, representing the Wai Subgroup. The entire column is made up of fine to medium grained, rarely coarse-grained, and highly massive to vesicular basalts. Massive basalt core samples are heavy and greenish black to dark black in color with metallic lustre. In comparison, vesicular samples, which are usually found at the top of the flows, are greyish brown to dark brown in color. Petrological and geochemical examination of these samples indicates that the studied basalt rocks are relatively $\mathrm{Fe}$ and $\mathrm{Mg}$-rich and silica deficient in composition and basically contain plagioclase, pyroxene phenocrysts, and microphenocrysts and occasionally, altered olivine as major constituents and magnetite and secondary silicates as accessory minerals. Quite a few samples are extremely glassy in nature (Fig. 2), while many of these contained abundant microlites and plagioclase laths. Some of the samples are filled with secondary minerals, and other forms of silicates, formed mainly by alteration of pyroxene and plagioclase grains.

The saturated massive basalt cores of the Deccan volcanic sequence have a mean density of $2.91 \mathrm{~g} / \mathrm{cm}^{3}$ and mean P- and S-wave velocities of $5.89 \mathrm{~km} / \mathrm{s}$ and $3.43 \mathrm{~km} / \mathrm{s}$ respectively. In comparison, vesicular basalts show a much lower density of 2.62 $\mathrm{g} / \mathrm{cm}^{3}$ as well as P- and S- wave velocities of 4.00 $\mathrm{km} / \mathrm{s}$ and $2.37 \mathrm{~km} / \mathrm{s}$ respectively. Based on this study, the Deccan volcanic sequence can be assigned a weighted mean density of $2.74 \mathrm{~g} / \mathrm{cm}^{3}$ and on an average, a quite low $\mathrm{V}_{\mathrm{p}}$ and $\mathrm{V}_{\mathrm{s}}$ of $5.00 \mathrm{~km} / \mathrm{s}$ and 3.00 $\mathrm{km} / \mathrm{s}$, respectively. Lowering in velocities can be primarily attributed to the presence of glassy material, high iron contents, and large-scale inclusion of 


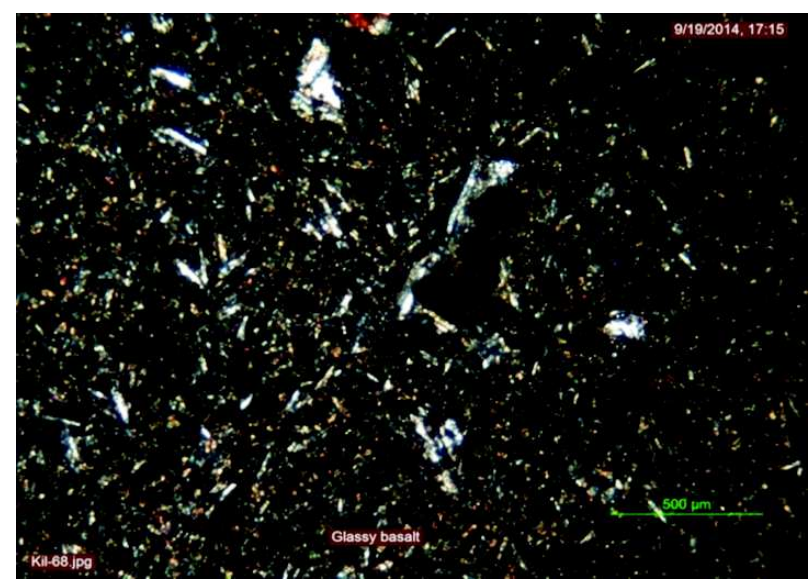

Fig. 2: Photomicrographs taken from the thin sections of Deccan basalt sample KIL-68 from the KLR-1 borehole drilled in Killari, showing glassy nature

secondary minerals. High order of attenuation is also reportedly noted in some of massive basalt cores, besides vesicular samples. It is argued that composition of the basalt itself could be a major contributing factor towards seismic attenuation. Recent studies over this region (Pandey et al., 2016) indicated that in comparison to Deccan volcanics, the subsurface thick Mesozoic sediments, can be seriously considered as a leading option for geologic $\mathrm{CO}_{2}$ sequestration, while pervasively fractured, faulted and highly deformed, on-land exposed volcanics, should be given least priority.

\section{Studies on Indian Carbonatites}

Carbonate magma is unique because of its ability to enrich elemental carbon with respect to its silicate mantle source, where carbon is a trace element. Owing to its extremely low viscosity and short residence time in the crust carbonate magma passes through the crust without significant contamination. In addition, very high contents of most of the incompatible trace elements, many of which are used as elemental or isotopic tracers in mantle studies, tend to buffer any such contamination. Therefore, carbonatites preserve mantle signatures more efficiently than most other magmatic rocks and thus are the best known samples to study the secular evolution of mantle geochemistry and the long-term carbon cycle in Earth.

Carbonatites occur both in continental and oceanic settings but are found mostly in the former and hence, provide useful information about the less understood sub-continental mantle. Even though they are volumetrically minor, because of their widespread spatial and temporal distribution they provide valuable information about the secular evolution of the subcontinental mantle on the whole-Earth scale. The observation that many carbonatites are associated with Large Igneous Provinces (LIPs) or Continental Flood Basalt (CFB) provinces has led to the speculation that they too like the LIPs/CFBs could be genetically linked to the deep mantle plumes. The plume derivation hypothesis derives its support, albeit unconvincingly, from the observations that many carbonatites (1) occur within LIPs or CFBs (Ernst and Bell, 2010), (2) carbonatites generally possess isotopic ratios of $\mathrm{Nd}$ $\mathrm{Sr}-\mathrm{Pb}$ similar to that of the Oceanic Island Basalts (e.g., Nelson et al., 1988), (3) show lower (undegassed) mantle noble gas isotopic signatures (Sasada et al., 1997; Tolstikhin et al., 2002), and (iv) have a HIMU (high ${ }^{238} \mathrm{U} /{ }^{204} \mathrm{~Pb}$ ) component, which is usually found in plume derived melts (Bell and Tilton, 2002). However, a great majority of carbonatites show (1) overwhelming presence in continental crust, (2) geochemical and isotopic signatures akin to lithospheric mantle (Ashwal et al., 2016), (3) repeated magmatic activity in a given complex, separated by several millions of years (e.g., Woolley and Bailey, 2012), (4) derivation from mantle that is much cooler than plumes (Bailey and Woolley, 1995), and alkaline silicate rock association and their diversification which would require significant involvement of continental lower crust (Ray, 2009). All these point to the possibility that carbonatite magmas most likely are derived from sub-continental lithospheric mantle. Other important aspects of carbonatite magmatism those have not been fully understood include, nature and source of carbon (primordial vs. recycled), nature of origin of magma (primary melt vs. magmatic differentiation), and environmental effects of the release of large amounts of fluids associated with its eruption/ emplacement.

The carbonatite complex in India was first discovered by Sukheswala and Udas (1963). Ever since, more than 20 complexes have been identified (Krishnamurthy et al., 2000; Ray and Ramesh, 2006). In spite of years of research, questions on the origin of many of these complexes remain poorly understood. Most of the Indian carbonatites occur within major fracture zones (Krishnamurthy et al., 2000) and some are associated with Deccan and 
Table 1: Summary of current chronological status of important carbonatite complexes of India

\begin{tabular}{|c|c|c|c|c|c|c|c|}
\hline & Complex & \multicolumn{2}{|c|}{ Age $(\mathrm{Ma} \pm 2 \mathrm{~s})$} & \multicolumn{2}{|c|}{ Dating Method } & Reference & Remark \\
\hline 1) & $\begin{array}{l}\text { Hogenakkal, } \\
\text { Tamil Nadu }\end{array}$ & \multicolumn{2}{|c|}{$2406 \pm 32$} & \multicolumn{2}{|c|}{$\begin{array}{l}\mathrm{Sm} / \mathrm{Nd} \text { min-wr isochron (carbonatite } \\
+ \text { pyroxenite }+ \text { minerals) }\end{array}$} & Kumar et al. (1998) & Weighted Mean of 3 age data \\
\hline 2) & $\begin{array}{l}\text { Kambamettu } \\
\text { (Kambam), } \\
\text { Tamil Nadu }\end{array}$ & $\begin{array}{l}\text { i. } \\
\text { ii. } \\
\text { iii. }\end{array}$ & $\begin{array}{l}2498 \pm 16 \& 2470 \pm 15 \\
\text { (magmatic) } \\
608 \pm 6 \text { (crustal?) } \\
715 \pm 42\end{array}$ & $\begin{array}{l}\text { i. } \\
\text { ii. } \\
\text { iii. }\end{array}$ & $\begin{array}{l}\mathrm{U} / \mathrm{Pb} \text { zircon } \\
\mathrm{U} / \mathrm{Pb} \text { zircon } \\
\mathrm{Th} / \mathrm{Pb} \text { monazite }\end{array}$ & $\begin{array}{l}\text { Renjith et al. (2016) } \\
\text { Renjith et al. }(2016) \\
\text { Catlos et al. }(2008)\end{array}$ & $\begin{array}{l}\text { Four phases of magmatic activity? } \\
\text { Age of monazite is deemed } \\
\text { hydrothermal (Ranjith et al., 2016) }\end{array}$ \\
\hline 3) & $\begin{array}{l}\text { Newania, } \\
\text { Rajasthan }\end{array}$ & $\begin{array}{l}\text { i. } \\
\text { ii. }\end{array}$ & $\begin{array}{l}1473 \pm 63 \text { (magmatic) } \\
904 \pm 2 \text { (thermal event) }\end{array}$ & $\begin{array}{l}\text { i. } \\
\text { ii. }\end{array}$ & $\begin{array}{l}\mathrm{Sm} / \mathrm{Nd} \text { wr isochron } \\
{ }^{40} \mathrm{Ar} /{ }^{39} \mathrm{Ar} \text { plateau (phlogopite) }\end{array}$ & Ray et al. (2013) & $\begin{array}{l}\text { Earlier age estimates: } 2.24 \mathrm{Ga} \text { to } \\
959 \mathrm{Ma}\end{array}$ \\
\hline 4) & $\begin{array}{l}\text { Sevattur, } \\
\text { Tamil Nadu }\end{array}$ & $\begin{array}{l}\text { i. } \\
\text { ii. } \\
\text { iii. }\end{array}$ & $\begin{array}{l}767 \pm 8 \\
801 \pm 11 \\
756 \pm 11\end{array}$ & $\begin{array}{l}\text { i. } \\
\text { ii. } \\
\text { iii. }\end{array}$ & $\begin{array}{l}\mathrm{Rb} / \mathrm{Sr} \text { wr isochron (syenite) } \\
\mathrm{Pb} / \mathrm{Pb} \text { isochron (carbonatite) } \\
\mathrm{Rb} / \mathrm{Sr} \text { isochron(syenite }+ \\
\text { pyroxenite) }\end{array}$ & $\begin{array}{l}\text { Kumar et al. (1998) } \\
\text { Schleicher et al. (1997) }\end{array}$ & $\begin{array}{l}\text { Accepted age: } 770 \mathrm{Ma} \text { (average } \\
\text { of all reliable ages) } \\
\text { Miyazaki et al. }(2000)\end{array}$ \\
\hline 5) & $\begin{array}{l}\text { Sung Valley, } \\
\text { Meghalaya }\end{array}$ & $\begin{array}{l}\text { i. } \\
\text { ii. }\end{array}$ & $\begin{array}{l}107.2 \pm 0.8 \\
106 \pm 11\end{array}$ & $\begin{array}{l}\text { i. } \\
\text { ii. }\end{array}$ & $\begin{array}{l}{ }^{40} \mathrm{Ar} /{ }^{39} \mathrm{Ar} \text { plateaus (phlogopite } \\
\text { from carbonatite }+ \text { pyroxenite) } \\
\mathrm{Rb} / \mathrm{Sr} \text { isochron (wr-mineral from } \\
\text { both carbonatite }+ \text { pyroxenite) }\end{array}$ & $\begin{array}{l}\text { Ray et al. (1999); } \\
\text { Ray and Pande (2001) } \\
\text { Ray et al. (2000) }\end{array}$ & Accepted age: $107 \mathrm{Ma}$ \\
\hline 6) & Jasra, Assam & 105. & \pm 0.5 & $\mathrm{U} / \mathrm{l}$ & of zircon/baddeleyite & Heaman et al. (2002) & \\
\hline 7) & $\begin{array}{l}\text { Mundwara, } \\
\text { Rajasthan }\end{array}$ & $\begin{array}{l}\text { i. } \\
\text { ii. }\end{array}$ & $\begin{array}{l}102-110 \\
80-84\end{array}$ & & ${ }^{9}$ Ar plateaus & Pande et al. (2017) & $\begin{array}{l}\text { Earlier age estimate: } 68 \text { Ma by Basu } \\
\text { et al. (1993); Repeated alkaline } \\
\text { magmatism }\end{array}$ \\
\hline 8) & $\begin{array}{l}\text { Sarnu-Dandali, } \\
\text { Rajasthan }\end{array}$ & $\begin{array}{l}\text { i. } \\
\text { ii. }\end{array}$ & $\begin{array}{l}88.9-86.8 \\
66.3 \pm 0.4\end{array}$ & $\begin{array}{l}\text { i. } \\
\text { ii. }\end{array}$ & $\begin{array}{l}{ }^{40} \mathrm{Ar} /{ }^{39} \mathrm{Ar} \text { plateaus (alkaline } \\
\text { silicates) } \\
{ }^{40} \mathrm{Ar} /{ }^{39} \mathrm{Ar} \text { plateau: (melanephenite) }\end{array}$ & Sheth et al. (2017) & Same as Mundwara \\
\hline 9) & $\begin{array}{l}\text { Chhota Udaipur } \\
\text { alkaline-carbonatite } \\
\text { sub-province, Gujarat }\end{array}$ & $\begin{array}{l}65.0 \\
t\end{array}$ & & & $\begin{array}{l}{ }^{9} \text { Ar plateaus(alkaline silicate } \\
\text { phlogopite from carbonatite) }\end{array}$ & $\begin{array}{l}\text { Ray and Pande (1999); } \\
\text { Ray et al. (2000); } \\
\text { Ray et al. (2005) }\end{array}$ & $\begin{array}{l}\text { Complexes/isolated bodies: } \\
\text { Amba Dongar; Siriwasan; Tawa }\end{array}$ \\
\hline
\end{tabular}


Rajmahal-Sylhet CFBs (Fig. 1). All except Newania are carbonatite-alkaline silicate rock complexes. The ages of emplacement of the important carbonatite complexes are reviewed in Table 1.

\section{Ages of Carbonatites Emplacements}

Based on available geochronological information, Indian carbonatites can be broadly classified into two groups. The southern Indian complexes and Newania of Rajasthan are Proterozoic (2500-750 Ma; Table 1); the northeastern and northwestern complexes are Cretaceous (110-65 Ma; Table 1). New age data suggest that Newania carbonatite was emplaced at $\sim 1473 \mathrm{Ma}$ and was affected by a thermal event at $\sim 904 \mathrm{Ma}$ (Ray et al., 2013), and these results contradict the earlier suggestion from $\mathrm{Pb}-\mathrm{Pb}$ ages that the complex had seen recurring carbonatite activities at $2270 \mathrm{Ma}$ and $1550 \mathrm{Ma}$ (Schleicher et al., 1997). However, the pre-Deccan alkaline-carbonatite complexes of Mundwara and Sarnu Dandali clearly had multiple activities during 110-66 Ma (Pande et al., 2017; Sheth et al., 2017), a finding that would likely to change our view on the LIP/CFB-carbonatite connection. Based on the U-Pb zircon data Kambamettu of Tamil Nadu becomes the oldest carbonatite-alkaline complex of India $(\sim 2.5 \mathrm{Ga}$; Renjith et al., 2016).

\section{Geology, Geochemistry and Mantle Sources}

Comprehensive reviews of general geology and geochemistry including isotopic compositions of Indian carbonatite-alkaline complexes can be found in Krishnamurthy et al. (2000) and Ray and Ramesh (2006). Here we shall present only the important geological and geochemical findings of the last five years, and their bearing on the origin and evolution of these complexes.

\section{Proterozoic Carbonatites}

All the southern Indian carbonatites, i.e., Hogenakal, Sevattur, Samalpatti, Jogipatti, Pakkandau, Kambamettu, and one north Indian complex, i.e., Newania, were emplaced at various times during the Proterozoic and most complexes show effects of one/ multiple post-magmatic thermal histories (e.g., Renjith et al., 2016; Ray et al., 2013). All these complexes are located within the Southern Granulite Terrain (SGT) and are associated with major fracture zones (Fig. 3).

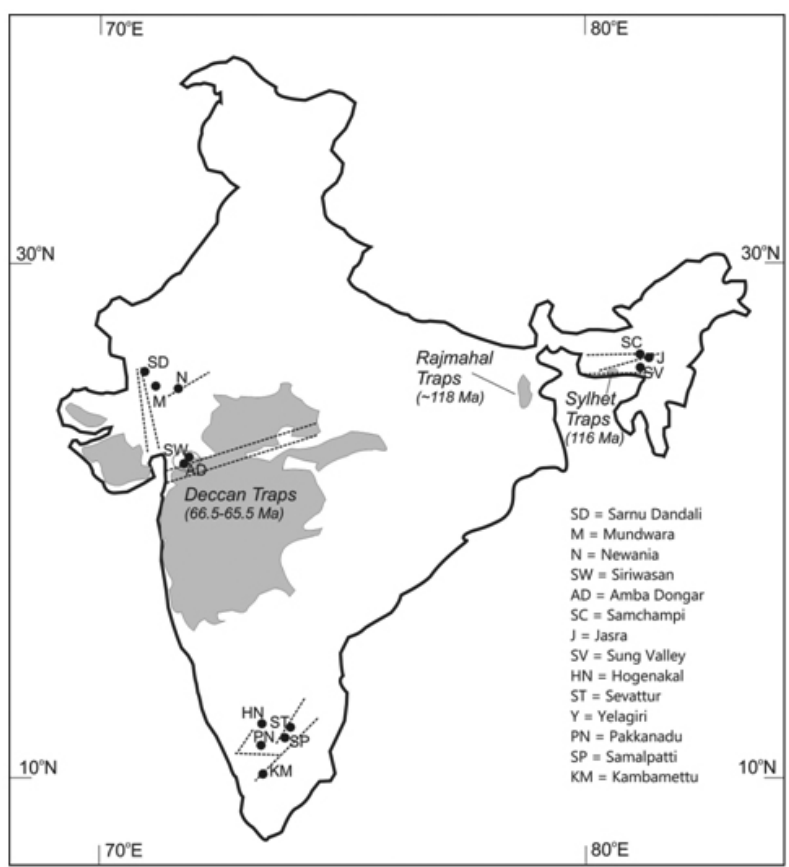

Fig. 3: Map of India (modified from Krishnamurthy et al., 2000), showing continental flood basalt provinces (grey shaded) and carbonatite complexes. Also shown are the major fracture zones/lineaments (dashed lines) in/along which the carbonatites occur. Ages of Deccan Traps, Rajmahal Traps and Sylhet Traps are from Renne et al. (2015), Bakshi (1995) and Ray et al. (2005), respectively

The most recent work on Kambamettu (Kambam) alkaline-carbonatite complex by Renjith et al. (2016) suggests that the complex had four distinct magmatic intrusions: i) quartz-monzonite (2.5 $\mathrm{Ga}$ ) derived from a carbonated alkali-rich lower crustal source; ii) phlogopite-rich pyroxenite derived from carbonate metasomatized mantle; iii) mantle derived high Ba-Sr carbonatite (2.47 Ga); and iv) shoshonitic peralkaline syenite $(0.61 \mathrm{Ga})$ derived from crustal source. We believe that the inference of crustal derivation for alkaline magmas is erroneous, what the younger ages and chemical compositions may actually mean is thermal resetting and/or metamorphism, and several such events, with the youngest being the 0.55 Ga Pan-African, are known to have affected the SGT. Pandit et al. (2016) carried out C-O-Sr-Nd isotopic study of the $2.4 \mathrm{Ga}$ Hogenakal carbonatites and suggested their derivation from a heterogeneous mantle source (LREE depleted and enriched). Mineral Chemistry, stable carbon and oxygen isotopes of carbonatite from Salem- Attur shear zone indicated 
the mantle origin of the southern Indian carbonatites. (Kumar et al. 2001). Ackerman et al. (2017)'s work is the most recent addition to the research on Sevattur and Samalpatti carbonatites that provides a large amount of petrographic, geochemical (major-trace elements) and isotopic (C-O-Sr-Nd-Pb) data. This study confirms the findings from previous studies that there has been significant hydrothermal alteration in these complexes (e.g., Ray and Ramesh, 2006), however, failed to identify the nature of the mantle sources because of significant crustal contamination. The only north Indian Proterozoic carbonatite is Newania, which happens to be a pure dolomite carbonatite complex that has no alkaline silicate rocks. Using multiple geochemical (major-trace elements and isotopic techniques (C-O-Sr-Nd-Pb) Ray et al. (2013) established that the primary magma for the complex was a magnesio-carbonatite melt and that it was derived from a carbonate bearing mantle. This work also suggested that the source was a phlogopite bearing, metasomatized continental lithospheric mantle, which was located within the garnet stability zone.

\section{Cretaceous Carbonatites}

All northeastern and western Indian carbonatite complexes, except Newania, were emplaced within a short time in Cretaceous, during $\sim 110$ and $65 \mathrm{Ma}$ (Table 1). Interestingly, these complexes are spatially and temporally associated with the Rajmahal-BengalSylhet and Deccan CFBs, respectively (Fig. 3) and have been hypothesized to have been generated directly or indirectly by the Reunion and Kerguelen plumes, respectively (Basu et al., 1993; Ray et al., 1999; Ernst and Bell, 2010; Ghatak and Basu, 2013).

The northeastern Indian carbonatites (Swangkre, Sung Valley, Jasra, Barpunga and Samchampi) intrude into Archean basement rocks of the Proterozoic Shillong Group. They occur in a horst like feature called the Assam-Meghalaya Plateau that is bound by two major fractures (Fig. 3). The 107 million year old alkaline-carbonatite complex of the Sung Valley happens to be the best studied northeastern Indian carbonatite (Ray and Ramesh, 2006; Ray, 2009). Based on geochemistry (elemental and $\mathrm{Sr}-\mathrm{Nd}-\mathrm{Pb}$ isotopic) of carbonatites and associated alkaline silicate rocks Ghatak and Basu (2013) suggested that Sung Valley carbonatites were derived from a relatively primitive carbonated garnet peridotite source in the Kerguelen plume. The work also envisaged a similar model for Samchampi. N and Ar isotopic compositions of Sung Valley carbonatites suggest involvement of recycled (atmospheric/crustal) component in the origin of carbonatite magma in a heterogeneous sub-continental mantle (Basu and Murty, 2015). Studying petrogenesis of Samchampi complex with the help of geochemical and isotopic (Sr-Nd) tracers Saha et al. (2017) proposed that these carbonatites were derived from a metasomatized peridotitic source (LREE enriched) within the Kerguelen plume, similar to what was suggested earlier by Ghatak and Basu (2013). However, these studies failed to explain the highly radiogenic nature of $\mathrm{Sr}\left({ }^{87} \mathrm{Sr} /{ }^{86} \mathrm{Sr}(\mathrm{i})>0.709\right)$ and non-radiogenic nature of $\mathrm{Nd}\left({ }_{\mathrm{Nd}}(\mathrm{i})<-8\right)$ in these rocks.

The western Indian Cretaceous carbonatites (Sarnu Dandali, Mundwara, Amba Dongar, Siriwasan, Panwad-Kawant) occur along two famous rift zones: the Barmer-Cambay and the Narmada-Son/Satpura (Fig. 3). Of these Amba Dongar, Siriwasan and many smaller plugs, dikes and extrusive bodies in PanwadKawant region of Chotta Udaipur district form a large alkaline-carbonatite subprovince within the Deccan LIP (Fig. 3; Gwalani et al., 1993; Ray et al., 2003). During the last five years only a couple of geochronological studies and one field based study have been done on Sarnu Dandali and Mundwara complexes (Tables 1 and 2). The works of Pande et al. (2017) and Sheth et al. (2017) suggest that there have been repeated alkaline magmatism in these two complexes after gaps of at least 20 and $40 \mathrm{Ma}$, respectively. These results clearly indicate that the initiation of magmatism in these complexes precedes the Deccan flood volcanism by a long time gap; therefore, the hypothesis of their origin from a DeccanReunion plume becomes untenable. Amba Dongar alkaline-carbonatite complex and its nearby smaller intrusive/extrusive bodies in Chotta Udaipur subprovince are by far the best studied carbonatites in India because of sustained efforts by Xavier College, Mumbai, Atomic Minerals Division, Gujarat Mineral Development Corporation and Physical Research Laboratory. Contributions by S.G. Viladkar and his group (e.g., Viladkar, 1996; Viladkar and Schidlowski, 2000; Simonetti et al., 1995) and J.S. Ray and his group (e.g., Ray, 1998; Ray and Pande, 1999; Ray and Ramesh, 1999; Ray and Ramesh, 2000; Ray et 
al., 2003; Ray and Ramesh 2006) have resolved most of the outstanding issues about the origin and evolution of Ambam Dongar and nearby complexes. The notable contributions for these complexes during the last five years have been by Basu and Murty (2015) and Chandra et al. (2017). The former presented $\mathrm{N}$ and Ar isotopic data from Amba Dongar carbonatites and suggested their derivation from a heterogeneous sub-continental mantle, a conclusion confirmed by a detailed geochemical study by Chandra et al. (2017). The latter study also substantiated the earlier claim made by Ray and Shukla (2004) and Ray (2009) that the carbonatites and alkaline silicate rocks of these complexes are derived from a single parental magma through liquid immiscibility and that lower crustal assimilation plays a critical role in their diversification.

\section{Studies on Kimberlites and Lamproites}

Significant advances have been made in the research frontiers of kimberlites and related rocks from the Indian context during past five years. Chalapathi Rao and his group at Banaras Hindu University have been very productive in studying mineralogical, petrological and chronological characterization of several kimberlite clusters of Mesoproterozoic (ca. $1100 \mathrm{Ma}$ ) and late Cretaceous (ca. $90 \mathrm{Ma}$ ). (Pandey et al. 2017; Dongre etal. 2017; 2016; Rao et al. 2016a; 2016b; 2017). From the paleomagnetic investigations on the 1.1 Ga Mesoproterozoic kimberlites from the Dharwar craton, southern India, Venkateshwarlu and Rao (2013) have shown that India, occupies a lower palaeolatitudinal position, was much separated from Australia and that East Gondwana very likely did not form an assembly until the terminal Neoproterozoic. A layered mantle stratigraphy has been documented in the sub-Bastar craton lithosphere from a comprehensive study of kimberlite- derived xenocrysts and xenoliths (Rao et al., 2013a). K-rich titanite, a characteristic mineral of orangeites, has been reported from ultrapotassic dykes of Jharia field, Damodar valley highlighting the transitional (lamprophyrelampropite-orangeite) characters (Rao et al., 2013b). PGE determination from the Deccan-age orangeites of Bastar craton, central India, lacks Ir enrichment thereby excluding the Ir enrichment at K-Pg boundary from deep mantle sources (Rao et al., 2013b). A number of previously undated kimberlites from the Wajrakarur field from the Dharwar craton gave precise $\mathrm{U}-\mathrm{Pb} 1.1 \mathrm{Ga}$ ages highlighting a major tectonomagmatic event during that time (Rao et al., 2013d). Contrasting lithospheric source regions for the kimberlites and lamproites from the Dharwar craton and for orangeites from the Bastar craton have been documented from Re-Os isotope systematics (Rao et al., 2013c). Nickeliferous silicate (garnierite) has been reported from the tuff facies Tokapal kimberlite and its prospectivity for nickel has been highlighted; petrogenesis of the Tokapal kimberlite has also been constrained (Rao et al. 2013d). A SCLM origin for Mesoproterozoic Ramadugu lamproites has been deduced (Rao et al., 2014). Imprints of Kerguelen plume have been confirmed in the melt sources of the ultrapotassic intrusives from the Gondwana sedimentary basins (Rao et al., 2014). Petrogenetic model has been proposed for the macrocrystic as well as aphanitic intrusions in the diamondiferous pipe-2 kimberlite of Wajrakarur field (Dongre et al., 2014). Ti-garnet occurrence in kimberlite groundmass as a resultant of breakdown of spinel has been delineated from the Wajrakarur field (Dongre et al., 2016). Petrogenetic studies and age determination have been carried out for the lamproites at Sakri, Bastar craton (Rao et al., 2016a) and Garledinne, Cuddapah basin (Rao et al ., 2016b) and their geodynamic significance brought out. A Late Cretaceous diamondiferous kimberlite event (90 Ma) has been documented for the first time from the Timmasamudram kimberlites, Wajrakarur field, Dharwar craton of southern India (Rao et al. 2016c) and their genesis has been brought out (Dongre et al., 2017). A cognate origin for the clinopyroxene megacrysts from the Udiripikonda lamprophyre, Dharwar craton has been deduced (Pandey et al. 2017a). The role of subduction tectonics in the modification of the SCLM beneath the Dharwar craton has been brought out from the geochemistry of calc-alkaline lamprophyres towards the western margin of the Cuddapah basin (Pandey et al., 2017b and c). Modal metasomatism, from phlogopite+apatite assemblage, has been documented for the first time beneath the sub-Deccan lithosphere in an ultramafic mantle xenolith entrained in a Eocene lamprophyre from the Dongargaon area, NW India (Pandey et al., 2017d). Single crystal geothermobarometry on a chrome diopside megacryst entrained in a lamprophyre from the polychromous (100-68 Ma) Mundwara alkaline Complex, NW India, implies that pre-Deccan lithosphere was $\sim 100 \mathrm{~km}$ depth. Phani et al. (2017) 
have discovered a new kimberlite in Lattavaram Kimberlite Cluster (LKC) of Anantapur district, Andhra Pradesh, India. This new kimberlite pipe has been located in the riverbed of Balkamthota Vanka (name of the stream used by local farmers) at its confluence with Penna River, close to Pennahobilam. The kimberlite constitutes olivine macrocrysts, serpentinsed olivine pseudomorphs with xenocrystic ilmenite, phlogopite, perovskite, magnetite, $\mathrm{Cr}$-diopside, garnet along with calcite veins. The kimberlite has been classified as hypabyssal macrocrystic calcitephlogopite kimberlite (Phani et al., 2017).

Lamproitic dykes from Sidhi Gnessic Complex, Central India have been investigated by Satyanarayanan et al. (2018), showing that lamproite magma attained carbonatitic character, underwent metasomatism at deep crustal level. The geochemical studies shown that the discovered Central Indian lamproitic dykes indicate their parental magmas were originated from a subduction induced metasomatism process contain phlogopite and garnet.

\section{Industrial Applications and Future Studies}

Deccan volcanic rocks provide several secondary minerals like zeolites, hydrous silica, and sulfates that are useful in many Industrial applications. Recent discovery of jarosite in Kutch area (Bhattacharya et al., 2016) not only serves as a Martian analog material, but also applied for adsorption and redox reactions occur between arsenic-containing pyrite and arsenate in the form of shwertmannite. Shwertmannite is proven to be a powerful scavenger for trivalent arsenic. Ferrous saponite from the Killari region of the Deccan Trap has been used in not only as for the study of Mars analogs system, but also for the

\section{References}

Ackerman L, Magna T., Rapprich, V, Upadhyay D, Krátký O, Ėejková B, Erban, V, Kochergina Y V and Hrstka T (2017) Contrasting petrogenesis of spatially related carbonatites from Samalpatti and Sevattur, Tamil Nadu India Lithos 284-285 257-275

Ashwal L D, Patzelt M, Schmitz M D and Burke K. (2016) Isotopic evidence for a lithospheric origin of alkaline rocks and carbonatites: an example from southern Africa Can J Earth Sci 53 1216-1226 adsorption and reduction of carcinogenic water soluble hexavalent chromium. Systematic studies of mineral chemistry of Indian carbonatites are found to be most useful in the exploration and utilization of rare-earth minerals. Future discovery of new carbonatites will be of tremendous use in improving the rare earth minerals resources of our country.

\section{Conclusion}

In this paper we presented a status report on the work carried out on Deccan Volcanism, carbonatites, and kimberlites during the last five years. There has been some significant advancement in terms of geochronology of Mundwara, Sarnu Dandali, Newania and Kambamettu carbonatites. Most other studies are on geochemistry and they mostly reaffirm the conclusions made by earlier studies. One clear conclusion, however, emerges from these studies is that the primary magmas for the Indian carbonatites originated from the sub-continental lithospheric mantle.

\section{Acknowledgements}

We thank Professor Harsh Gupta for inviting us to write this status review related to IAVCEI research in India, and his kind support and encouragements. We thank the anonymous reviewers for their useful comments and suggestions. We thank CSIR-NGRI and PRL-PLANEX for financial support and encouragements. We thank Professor N V Chalapathi Rao of Banaras Hindu University, Varanasi, Dr. O P Pandey of CSIR-NGRI for very useful discussion on their contributions in kimberlite and Killari borehole respectively. This paper is dedicated to our colleague Late Professor R Ramesh of Physical Research Laboratory.

Bailey D K and Woolley A R (1995) Magnetic quiet periods and stable continental magmatism: can there be a plume dimension? In: Anderson D L, Hart S R and Hofmann A W (Eds.). Terra Nostra, Alfred-Wegener-Stiftung, Bonn, pp. $15-19$

Baksi A K (1995) Petrogenesis and timing of volcanism in the Rajmahal flood basalt province, northeastern India Chem Geol 121 73-90

Basu S and Murty S V S (2015) Nitrogen and argon in Sung Valley and Ambadongar carbonatite complexes: Evidence of incomplete homogenization of mantle and recycled 
components J Asian Earth Sci 107 53-61

Basu A R, Renne P R, Das Gupta D K, Teichman F and Poreda R $\mathrm{J}$ (1993) Early and late alkali igneous pulses and a high ${ }^{3} \mathrm{He}$ plume origin for the Deccan flood basalts Science $261902-$ 906

Bhattacharya S, Mitra S, Gupta S, Jain S, Chauhan P, Parthasarathy G and Ajai (2016) Jarosite occurrence in the Deccan Volcanic Province (DVP) of Kachchh, Western India: Spectroscopic studies on a martian analog locality $J$ Geophys Res Planets 121 402-431 doi: 10.1002/2015 JE004949

Catlos E J, Dubey C S and Sivasubramanian P (2008) Monazite ages from carbonatites and high-grade assemblages along the Kambam Fault (Southern Granulite Terrane, South India) Am Miner 93 1230-1244

Chandra J, Paul D, Viladkar S G and Sensarma S (2017) Origin of the Amba Dongar carbonatite complex, India and its possible linkage with the Deccan Large Igneous Province Geol Soc London Sp. Pub. 463 https://doi.org/10.1144/ SP463.3

Dongre A, Rao N V C and Malandkar M (2014) Petrogenesis of macrocrystic and aphanitic intrusions in Mesoproterozoicdiamondiferous pipe 2 kimberlite, Wajrakarur kimberlite field, eastern Dharwar craton, southern India Geochemical Journal 48 pp 491-507

Dongre A N Viljoen K S, Rao N V C and Lehmann B (2017) Petrology, genesis and geodynamic implication of the Mesoproterozoic-Late Cretaceous Timmasamudram kimberlite cluster, Wajrakarur field, Eastern Dharwar craton, southern India Geoscience Frontiers 8 541-553

Dongre A N, Viljoen K S, Rao N V C and Gucsik A (2016) Origin of Ti-rich garnets in the groundmass of Wajrakarur field kimberlites, southern India: insights from EPMA and Raman Spectroscopy Mineralogy and Petrology 110295 307

Ernst R E and Bell K (2010) Large igneous provinces (LIPs) and carbonatites Miner Petrol 98 55-76

Fareeduddin and Mitchell R H (2012) Diamonds and their Source rocks in India, Geological Society of India

Ghatak A and Basu A R (2013) Isotopic and trace element geochemistry of alkalic-mafic-ultramafic-carbonatitic complexes and flood basalts in NE India: Origin in a heterogeneous Kerguelen plume Geochim Cosmochim Acta $11546-72$

Gupta H K (2017) Koyna, India, an Ideal site for Near Field Earthquake Observations J Geological Soc India 90645 652 and references cited therein

Gwalani L G, Rock N M S, Chang W J, Fernandez S, Alle'gre C
J and Prinzhofer A (1993) Alkaline rocks and carbonatites of Amba Dongar and adjacent areas, Deccan Igneous Province, Gujarat, India: 1. Geology, Petrography and Petrochemistry Mineral Petrol 47 219-253

Hari K, Rao N V C, Swarnakar V and Hou G (2014) Alkali feldspar syenites with shoshonitic affinities from Chhotaudepur area: Implication for mantle metasomatism in the Deccan large igneous province Geoscience Frontiers 5 261-276

Heaman L M, Srivastava R K and Sinha A K (2002) A precise U$\mathrm{Pb}$ zircon/baddeleyite age for the Jasra igneous complex, Karbi-Anglong District, Assam, NE India Curr Sci 82 744748

Krishnamurthy P, Hoda S Q, Sinha R P, Banerjee D C and Dwivedy K K (2000) Economic aspects of carbonatites of India J Asian Earth Sci 18 229-235

Kumar A, Charan S N, Gopalan K and Macdougall J D (1998) A long-lived enriched mantle source for two Proterozoic carbonatite complexes from Tamil Nadu, southern India Geochim Cosmochim Acta 62 515-523

Kumar P S, Parthasarathy G, Sharma S D, Srinivasan R and Krishnamurthy P (2001) Mineralogical and Geochemical Study on Carbonate Veins of the Salem-Attur Fault Zone, Southern India: Evidence for Carbonatitic Affinity Jour Geological Society of India 24 15-26

Miyazaki T, Kagami H, Shuto K, Morikiyo T, Ram Mohan V and Rajasekaran K C (2000) Rb-Sr geochronology, Nd-Sr isotopes and whole rock geochemistry of Yelagiri and Sevattur syenites, Tamil Nadu, south India Gond Res 3 $39-53$

Nelson D R, Chivas A R, Chappel B W and McCulloch M T (1988) Geochemical and isotopic systematics in carbonatites and implications for the evolution of oceanicisland sources Geochim Cosmochim Acta 52 1-17

Pande K, Cucciniello C, Sheth H, Vijayan A, Sharma K K, Purohit R, Jagadeesan K C and Shinde S (2017) Polychronous (Early Cretaceous to Palaeogene) emplacement of the Mundwara alkaline complex, Rajasthan, India: ${ }^{40} \mathrm{Ar} /{ }^{39} \mathrm{Ar}$ geochronology, petrochemistry and geodynamics Int $J$ Earth Sci (Geol Rundsch) 106 1487-1504

Pandey A, Rao N V C, Pandit D, Pankaj P, Pandey R, Sahoo S and Kumar A(2017a) Subduction tectonics in the evolution of the Eastern Dharwar craton, southern India: insights from the post-collisional calc-alkaline lamprophyres at the western margin of the Cuddapah basin Precambrian Research 298 235-251

Pandey A, Rao N V C, Chakrabarti, R, Pandit D, Pankaj P, Kumar A and Sahoo S (2017b) Petrogenesis of a Mesoproterozoic 
shoshonitic lamprophyre dyke from the Wajrakarur kimberlite field, eastern Dharwar craton, southern India: Geochemical and $\mathrm{Sr}-\mathrm{Nd}$ isotopic evidence for a modified sub-continental lithospheric mantle source Lithos 292218 233

Pandey O P (2016). Deep Scientific drilling results from Koyna and Killari earthquake regions reveal why Indian shield lithosphere is unusual, thin and warm Geoscience Frontiers $7851-858$

Pandey O P, Tripathi P, Parthasarathy G, Rajagopalan V and Sreedhar B (2014) Geochemical and mineralogical studies of chlorine-rich amphibole and biotite from the 2.5 Ga mid-crustal basement beneath the 1993 Killari earthquake region, Maharashtra, India: Evidence for mantle metasomatism beneath the Deccan Traps? Journal of the Geological Society of India $\mathbf{8 3} 599-612$

Pandey O P, Tripathi P, Vedanti N and Sarma D S (2016) Anomalous seismic velocity drop in iron and biotite rich amphibolite to granulite facies transitional rocks from Deccan volcanic covered 1993 Killari earthquake region, Maharastra (India): A case study Pure and applied Geophys 173 2455-2471

Pandey R, Rao N V C, Pandit D, Sahoo S and Dhote P (2017) Imprints of modal metasomatism in the post-Deccan subcontinental lithospheric mantle: petrological evidence from the ultramafic xenolith in an Eocene lamprophyre, NW India Geological Society of London Special Publications 463 117-136

Pandit M K, Kumar M, Sial A N, Sukumaran G B, Piementle M and Ferreira V P (2016) Geochemistry and C-O and Nd$\mathrm{Sr}$ isotope characteristics of the $2.4 \mathrm{Ga}$ Hogenakkal carbonatites from the South Indian Granulite Terrane: evidence for an end-Archaean depleted component and mantle heterogeneity Int Geol Rev 58 1461-1480

Parthasarathy G (2006) Effect of high-pressures on the electrical resistivity of natural zeolites from Deccan Trap, Maharashtra, India Jour Applied Geophysics 58 321-329

Parthasarathy G, Choudary B M, Sreedhar B, Kunwar A C and Srinivasan R (2003) Ferrous saponite from the Deccan Trap, India, and its application in adsorption and reduction of hexavalent chromium American Mineralogist 88 19831988

Rao N V C, Atiullah, Alok Kumar, Sahoo S, Nanda P, Chahong N, Lehmann B and Rao K V S (2016a) Petrogenesis of Mesoproterozoic lamproite dykes from the Garledinne (Banganapalle) cluster, south-western Cuddapah Basin, southern India Mineralogy and Petrology 110 247-268

Rao N V C, Atiullah, Burgess R, Nanda P, Choudhary A K, Sahoo
S., Lehmann B and Chahong N (2016b) Petrology, 40Ar/ 39Ar age, $\mathrm{Sr}-\mathrm{Nd}$ isotope systematics, and geodynamic significance of an ultrapotassic (lamproitic) dyke with affinities to kamafugite from the eastern-most margin of the Baster Craton, India Mineralogy and Petrology 110 269-293

Rao N V C and Dongre N (2015) An alternate perspective on the opening and closing of the intracratonic Purana basins in peninsular India - Correspondence Journal of the Geological Society of India 86 118-119

Rao N V C, Alok Kumar, Sahoo S, Dongre A and Talukdar D (2014) Petrology and petrogenesis of Mesoproterozoic lamproites from the Ramadugu field, NW margin of the Cuddapah basin, eastern Dharwar craton, southern India Lithos 196-197 150-168

Rao N V C, Sinha A K, Suresh Kumar and Srivastava R K (2013b) K-rich titanite from the Jharia ultrapotassic rock, Gondwana coal fields, Eastern India, and its petrological significance Journal of the Geological Society of India $\mathbf{8 1}$ 733-736

Rao N V C, Wu F Y, Mitchell R H, Li L Q and Lehmann B (2013c) Mesoproterozoic U-Pb ages, trace element and $\mathrm{Sr}-\mathrm{Nd}$ isotopic composition of perovskite from kimberlites of the Eastern Dharwar craton, southern India: Distinct mantle sources and a widespread $1.1 \mathrm{Ga}$ tectonomagmatic event Chemical Geology 353 48-64

Rao N V C, Srivastava R K, Sinha A K and Ravikant V (2014b) Petrogenesis of Kerguelen-plume linked ultrapotassic intrsuives from the Gondwana Sedimentary basins, Damodar valley, eastern India Earth-Science Reviews 136 96-120

Rao N V C, Lehmann B, Panwar B K, Kumar A and Mainkar D (2013d) Tokapal tuff-facies kimberlite, Bastar craton, central India: A nickel prospect? Journal of the Geological Society of India 82 595-600

Ray J S (1998) Trace element and isotope evolution during concurrent assimilation, fractional crystallization, and liquid immiscibility of a carbonated silicate magma Geochim Cosmochim Acta 62 3301-3306

Ray J S (2009) Radiogenic Isotopic RatioVariations in Carbonatites and Associated Alkaline Silicate Rocks: Role of Crustal Assimilation J Petrol 50 1955-1971

Ray J S and Pande K (1999) Carbonatite-alkaline magmatism associated with continental flood basalts at stratigraphic boundaries: cause for mass extinctions Geophys Res Lett 26 1917-1920

Ray J S and Pande K (2001) 40Ar-39Ar age of carbonatitealkaline magmatism in Sung Valley, Meghalaya, India Proc 
Indian Acad Sci (Earth Planet Sci) 110 185-190

Ray J S, Pande K, Bhutani R, Shukla A D, Rai V K, Kumar, Awasthi N, Smitha R S and Panda D K (2013) Age and geochemistry of the Newania dolomite carbonatites, India: implications for the source of primary carbonatite magma Contrib Mineral Petrol 166 1613-1632

Ray J S, Pande K and Venkatesan T R (2000) Emplacement of Amba Dongar carbonatite-alkaline complex at Cretaceous/ Tertiary boundary: Evidence from ${ }^{40} \mathrm{Ar}-{ }^{39} \mathrm{Ar}$ chronology Proc Indian Acad Sci (Earth Planet Sci) 109 39-47

Ray J S, Pattanayak S K and Pande K (2005) Rapid emplacement of the Kerguelen plume-related Sylhet Traps, eastern India: Evidence from ${ }^{40} \mathrm{Ar}-{ }^{39} \mathrm{Ar}$ geochronology Geophys Res Lett 32 L10303, doi:10.1029/2005GL022586

Ray J S and Ramesh R (1999) Evolution of carbonatite complexes of the Deccan flood basalt province: Stable carbon and oxygen isotopic constraints J Geophys Res 10429471 29483

Ray J S and Ramesh R (2000) Rayleigh fractionation of stable isotopes from a multicomponent source Geochim Cosmochim Acta 64 299-306

Ray J S and Ramesh R (2006) Stable Carbon and Oxygen Isotopic Compositions of Indian Carbonatites Int Geol Rev 48 1745

Ray J S, Ramesh R and Pande K (1999) Carbon isotopes in Kerguelen plume derived carbonatites: evidence for recycled inorganic carbon Earth Planet Sci Lett 170 205-214

Ray J S, Trivedi J R and Dayal A M (2000) Strontium isotope systematics of Amba Dongar and Sung Valley carbonatitealkaline complexes, India: Evidence for liquid immiscibility, crustal contamination and long-lived $\mathrm{Rb} / \mathrm{Sr}$ enriched mantle sources J Asian Earth Sci 18 585-594

Ray J S, Pande K and Pattanayak S K (2003) Evolution of Amba Dongar carbonatite complex: Constraints from ${ }^{40} \mathrm{Ar}-{ }^{39} \mathrm{Ar}$ chronologies of the Inner Basalt and an alkaline plug Int Geo Rev 45 857-862

Ray J S and Shukla P N (2004) Trace element geochemistry of Amba Dongar carbonatite complex, India: Evidence for fractional crystallization and silicate-carbonate melt immiscibility Proc Ind Acad Sci (Earth Planet Sci) 113 113

Renjith M L, Charan S N, Subbarao D V, Babu E V S S K and Rajashekhar V B (2014) Grain to outcrop-scale frozen moments of dynamic magma mixing in the syenite magma chamber, Yelagiri Alkaline Complex, South India Geosci Front 5 801-820

Renne P R, Sprain C J, Richards M A, Self S, Vanderkluysen L and Pande K (2015) State shift in Deccan volcanism at the Cretaceous-Paleogene boundary, possibly induced by impact Science 350 76-78

Rohilla S, Kumar M R, Rao N P and Satyanarayana H V S (2011) Shear Wave Velocity Structure of the Koyna-Warna Region, Western India, through Modeling of P-Receiver Functions Bulletin of Seismological Society of America 108 1314-1325

Saha A, Ganguly S, Ray J S, Koeberl C, Thöni M Sarbajna C and Sawant S S (2017) Petrogenetic evolution of Cretaceous Samchampi-Samteran Alkaline Complex, Mikir Hills, Northeastern India: Implications on multiple melting events of heterogeneous plume and metasomatized subcontinental lithospheric mantle Gond Res 48 237-256

Sasada T, Hiyagon H, Bell K and Ebihara M (1997) Mantlederived noble gases in carbonatites Geochim Cosmochim Acta 61 4219-4228

Satyanarayanan M, Rao D V S, Renjith M L, Singh S P and Babu E V S S K (2018) Petrogenesis of carbonatititc lamproitic dykes from Sidhi gneissic complex, Central India Geoscience Frontiers 9 531-547

Schleicher H, Todt W, Viladkar S G and Schmidt F (1997) Pb/Pb age determinations on Newania and Sevattur carbonatites of India: Evidence for multi-stage histories Chem Geol 140 291-273

Sharma A, Kumar D, Sahoo S, Pandit D and Rao N V C (2018) Chrome-diopside Megacryst-bearing Lamprophyre from the Late Cretaceous Mundwara Alkaline Complex, NW India: Petrological and Geodynamic Implications Journal of Geological Society of India 91 395-399

Sheth H, Pande K, Vijayan A, Sharma K K and Cucciniello C (2017) Recurrent Early Cretaceous, Indo-Madagascar (89$86 \mathrm{Ma}$ ) and Deccan (66 Ma) alkaline magmatism in the Sarnu-Dandali complex, Rajasthan: ${ }^{40} \mathrm{Ar} /{ }^{39} \mathrm{Ar}$ age evidence and geodynamic significance Lithos 284-285 512-524

Simonetti A, Bell K and Viladkar S G (1995) Isotopic data from the Amba Dongar carbonatite complex, west-central India: Evidence for an enriched mantle source Chem Geol 122 185-198

Srinivasaiah C, Vasudev V N and Rao N V C (2015) Tungsten, Barium and Basemetal Mineralization in a layer of Amphibolite in Mesoarchean Ghattihosarahalli Belt, Western Dharwar craton, Karnataka Journal of the Geological Society of India 86 648-656

Subbarao K V (1999) Deccan Volcanic Province, Geological Society of India Vol.1 400 vol 2547

Sukheswala R N and Udas G R (1963) Note on the carbonatite of Amba Dongar and its economic potentialities Sci and Cult 
29 563-568

Tolstikhin I N, Kamensky I L, Marty B, Nivin V A, Vetrin V R, Balaganskaya E G, Ikorsky S V, Gannibal M A, Weiss D, Verhulst A and Demaiffe D (2002) Rare gas isotopes and parent trace elements in ultrabasic-alkaline-carbonatite complexes, Kola Peninsula identification of lower mantle plume component Geochim Cosmochim Acta 66 881-901

Tripathi P, Pandey O P, Rao M V M S and Reddy G K (2012a) Elastic properties of amphibolite and granulite facies midcrustal basement rocks of the Deccan volcanic covered 1993 Latur-Killari earthquake region, Maharashtra (India) and mantle metasomatism Tectonophysics 554-557 159168

Tripathi P, Parthasarathy G, Ahmad S M and Pandey O P ( 2012b) Mantle derived fluids in the basement of the Deccan traps: Evidence from stable carbon and oxygen isotopes of carbonates from the Killari borehole basement , Maharashtra, India Int Jour Earth Sci 101 1385-1395

Venkateswarlu M and Rao N V C (2013) New Paleomagnetic and rock magnetic results on Mesoproterozoic kimberlites from the Eastern Dharwar craton, southern India: towards constraining India's position in Rodinia Precambrian Research 224 588-596

Vijayan A, Sheth H and Sharma K K (2016) Tectonic significance of dykes in the Sarnu-Dandali alkaline complex, Rajasthan, northwestern Deccan Traps Geosci Front 7 783-791

Viladkar S G (1996) Geology of the carbonatite-alkalic diatreme of Amba Dongar, Gujarat, GMDC, Ahmedabad
Viladkar S G (2015) Mineralogy and geochemistry of fenitized nephelinites of the Amba Dongar complex, Gujarat Journal of the Geological Society of India 85 87-97

Viladkar S G (2017) Pyroxene-sövite in Amba Dongar carbonatitealkalic complex, Gujarat Journal of the Geological Society of India 90 591-594

Viladkar S G and Bismayer U (2014) U-rich Pyrochlore from Sevathur Carbonatites, Tamil Nadu Journal of the Geological Society of India 83 147-154

Viladkar S G, Bismayer U and Zietlow P (2017) Metamict U-rich pyrochlore of Newania carbonatite, Udaipur, Rajasthan Journal of the Geological Society of India 89 133-138

Viladkar S G and Gittins J (2016) Trace elements and REE geochemistry of Siriwasan carbonatite, Chhota Udaipur, Gujara Journal of the Geological Society of India 87 709715

Viladkar S G and Schidlowski M (2000) Carbon and oxygen isotope geochemistry of the Amba Dongar carbonatite complex, Gujarat, India Gond Res 3 415-424

Viladkar S G and Ramesh R (2014) Stable Isotope geochemistry of some Indian Carbonatites: Implications for magmatic processes and post-emplacement hydrothermal alteration. Comunicações Geológicas 101 55-62

Woolley A R (1989) The spatial and temporal distribution of carbonatites. In: Carbonatites: Genesis and Evolution. Bell K. (Eds), Unwin Hyman, London, pp. 15-37

Woolley A R and Bailey D K (2012) The crucial role of lithospheric structure in the generation and release of carbonatites: geological evidence Miner Mag 76 259-270. 